\title{
ASSOCIATION BETWEEN HUMAN PARVOVIRUS B19 AND ARTHROPATHY IN BELÉM, PARÁ, NORTH BRAZIL
}

Ronaldo B. FREITAS(1), Talita A.F. MONTEIRO(1), Manoel G. SILVA FILHO(2) \& Alexandre C. LINHARES(1)

\begin{abstract}
SUMMARY
A total of 220 patients with arthropathy were selected in Belém, Pará between January 1994 and December 2000, and screened for the presence of human parvovirus B19 IgM and IgG antibodies by enzyme-linked immunosorbent assay (ELISA). A subgroup (n $=132$ ) of patients with high levels of antibodies (either IgM+/IgG+ or IgM-/IgG+) were examined for the presence of DNA by polymerase chain reaction/nested PCR. Recent/active infection (detection of IgM and/or IgG-specific antibodies and presence of viral DNA) was identified in $47.7 \%$ of the 132 individuals with arthropathy. In our study, women were significantly more affected (59.7\%) than men $(35.4 \%)(\mathrm{P}=0.0006)$. The age group of $11-20$ years $(84.6 \%)$, among female patients, and $21-30$ years $(42.1 \%)$, among male, were those with the highest incidence rates. The analysis of the temporal distribution of B19-associated arthropaties showed a cyclic pattern, with peak incidence rates occuring at 3-5 year intervals. Significant diference $(\mathrm{P}=0.01)$ was observed when comparing both the highest $(39.0 \%)$ and the lowest $(11.0 \%)$ seropositivity rates for the years of 1995 and 2000, respectively. The interfalangial joints of hands and feet were mostly affected, with $50.0 \%$ and $48.0 \%$ of cases among both women and men, respectively. In a smaller proportion, other joints such as those of knee, ankle, pulse and shoulder were affected. As for the duration, symptoms lasted 1 to 5 days in $54.0 \%$ of the individuals, whereas in $46.0 \%$ of them the disease lasted $6-10$ days, if considered the subgroup ( $n=63$ ) of patients with recent/active infection by parvovirus B19. In our study, joint clinical manifestations occurred symmetrically. Our results indicate that B19 may be an important agent of arthropathies in our region, and this underscores the need for specific laboratory diagnosis when treating patients suffering from acute arthropathy, mainly pregnant women.
\end{abstract}

KEYWORDS: Parvovirus B19; Acute arthropathy.

\section{INTRODUCTION}

Human parvovirus B19, discovered by COSSART et al. ${ }^{15}$, belongs to the family Parvoviridae, genus Erytrovirus ${ }^{39}$. The B19 transmission occurs mainly through respiratory secretions following human-to-human close contacts $^{4,50}$. The B19 infection is quite common, affecting children and adults, often being asymptomatic ${ }^{13,53}$. The erythema infectiosum (EI) is the most common clinical presentation of the B19 infection in children. In adults, the primary B19 infection has been associated with arthropathy, transient aplastic crises (TAC) in patients suffering from chronic haemolytic anemia, and chronic anemia in immunocompromised patients. Hydrops fetalis may develop as a consequence of infection during the second trimester of the pregnancy ${ }^{11,16,42,45,52}$.

Several viral agents have been implicated in the occurrence of the acute and chronic arthropathies. In the Amazon region, arthropathy is a common finding in rubella, arboviral diseases (ex.: Oropouche and Mayaro fevers), Epstein-Barr virus infection and cytomegalovirus infection $^{1,23,38,51}$. Among of the parasitic and bacterial agents, Toxoplasma gondii and Streptoccocus species may also cause arthropathy ${ }^{19,31}$.
The pathogenesis of B19 arthropathy needs to be fully elucidated. Previous studies support the assumption that the joint lesions are associated with immune complexes ${ }^{40,47}$. In addition, the tissue joint lysis caused by parvovirus B19 has been postulated ${ }^{33}$. The chronic joint lesions has been associated with persistence of the viral agent in the tissue and synovial fluid ${ }^{20,34,35}$.

Several studies conducted in temperate countries $^{2,7,10,24,36,40,44,47}$ have reported the joint involvement in association with recent/active B19 infections, with rates ranging from 30.0 to $59.0 \%$ among male and female adult patients, respectively. Furthermore, joint involvement has been reported in $8.0 \%$ children of both sexes. In tropical climate countries, like Brazil, there have been a few reports associating these viral agent with cases of arthropathy. Overall, these studies ${ }^{37,38}$ have shown that arthropathy is present among individuals with exanthematous illness, namely E.I, and the positivity rates usually range from 10.0 to $40.0 \%$ in men and women, respectively. It is therefore of our interest to improve our knowledge on the epidemiology/clinical features of parvovirus B19 infection in our region focussing on its potential for developing arthropathies. 


\section{MATERIAL AND METHODS}

The study was conducted in Belém, Pará between January, 1994 and December, 2000. A total of 220 blood samples were collected from individuals with arthropathies (arthritis and/or arthralgy) at the Virology Section of "Instituto Evandro Chagas". This subgroup of patients ( $=$ 220) was selected from 3,000 individuals with arthropathies who tested negative for the following agents: measles, rubella, cytomegalovirus, Epstein-Barr virus, arbovirus (Mayaro, Oropouche and dengue), Toxoplasma gondii and Streptococcus. Of these, 114 patients were female and 106 were male, with ages ranging from 2 to 68 years (mean age, 35 years). The blood samples were collected by antecubital venepuncture. Sera were kept at $-20^{\circ} \mathrm{C}$ until processing.

The detection of IgM and IgG antibodies to parvovirus B19 was made using a commercial enzyme-linked immunosorbent assay (ELISA) developed by DENKA SEIKEN ${ }^{\mathrm{TM}}$ (Tokyo, Japan). This is an assay that includes a solid-phase multiple-wells system coated with anti-human IgM monoclonal antibody, as previously described ${ }^{6,43}$. Lyophilized, purified human parvovirus B19 recombinant antigen was used. Sensitivity and specificity of this assay have been found to be $100 \%$ and $97 \%$, respectively, as based on its comparison with the (gold standard) radioimmunoassay ${ }^{14}$. Sera were tested at a (single) dilution of 1:200, according to the manufacturer. The results of ELISA were calculated dividing optical density (O.D) values of serum samples by the mean absorbance of cut-off. The serum samples with IgM antibodies with absorbance $\geq 1.00$ were regarded as positive.

A subgroup $(\mathrm{n}=132)$ of individuals with B19 $\operatorname{IgM}+/ \operatorname{IgG}+$ antibodies (absorbance, $\geq 1.00$ ) and IgM-/IgG+ (O.D of serum samples $>5$ times the mean O.D of cut-off) were selected for the B19 DNA detection, using the polymerase chain reaction (PCR). The PCR technique was performed in two steps, essentially as reported before ${ }^{18,32}$. First, amplification was done using a mixture of external oligonucleotide primers (P1 and P6), followed by a second amplification (the nested PCR) that involved a mixture of the internal primers $\mathrm{P} 2$ and $\mathrm{P} 5$. The $\mathrm{B} 19$ recent/active infection was defined as the presence of IgM+ and/or IgG specific antibodies plus viral DNA detection in this subgroup $(\mathrm{n}=132)$ of selected individuals. Conventional ELISA and immunofluorescence indirect assays were used for the detection of both IgM and IgG antibodies to rubella, measles, Epstein-Barr virus, cytomegalovirus and Toxoplasma gondii, as previously reported ${ }^{8,12,17,25,29}$. Serum specimens were also tested by haemagglutination-inhibition (HI), as described before ${ }^{46}$, for the determination of antibodies to Mayaro, Oropouche and dengue viruses, which are well-know viral agents of exanthematous illnesses in the Amazon region. The latex assay was used for the detection of the antiestreptolysin O, for the diagnosis of infection by Streptococcus as a possible cause of rheumatic fever, as previously described ${ }^{30}$, in a subgroup $(n=12)$ of patients that presented with tonsillar pharyngitis.

The data were analysed using the EPI-INFO software, version 6.0 (Atlanta, GA, USA). Rates were compared by using the Mantel-Haenszel chi square test of association or Fisher's exact test, as appropriate. Significance was defined as $\mathrm{P}<0.05$.

\section{RESULTS}

Nineteen $(8.6 \%)$ of the 220 patients were IgM and IgG positive (IgM+/ $\mathrm{IgG}+)$ to B19 (Table 1). One hundred and sixty nine patients $(76.8 \%)$ were identified as being immune, since they were $\mathrm{IgM}-/ \mathrm{IgG}+$, and 32 (14.6\%) of them had neither IgM nor IgG antibodies (IgM-/IgG-). The results of PCR and nested PCR are shown in the Table 2 . The viral DNA was detected in $17(12.9 \%)$ and $46(34.8 \%)$ of the 132 patients who were either $\operatorname{IgM}+/ \operatorname{IgG}+(\mathrm{n}=19)$ and $\operatorname{IgM}-/ \operatorname{IgG}+(\mathrm{n}=113)$, respectively. The detection of B19 DNA among female and male patients were $59.7 \%$ and $35.4 \%$, respectively (Table 2). Significant difference was observed when comparing the joint involvement in the subjects of both sexes: $\mathrm{P}=0.0006$ (a vs b) and $\mathrm{P}=0.005$ (c vs d) for the age groups 11-20 years and the subtotal, respectively (Table 2 ). In the children $\leq 10$ years of age, B19 DNA positive rates ranged from 50.0 to $75.0 \%$. The age groups $11-20$ years $(84.6 \%)$, among female patients, and $21-30$ years $(42.1 \%)$, among male, were those with the highest incidence rates. Significant difference was observed when comparing these two age groups $(\mathrm{P}=0.01)$.

The analysis of the temporal distribution of B19-associated arthropathies shows a cyclic pattern, with peak incidence rates at 3-5 years intervals. Significant difference $(\mathrm{P}=0.01)$ was observed when comparing both the highest (39.0\%) and the lowest (11.0\%) seropositivity rates, corresponding to 1995 and 2000, respectively (Fig. 1).

The interfalangial joints of hands and feet were mostly affected, with $50.0 \%$ and $48.0 \%$ (data not shown in Fig. 2) of cases among both women and men, respectively. In a smaller proportion of patients, other

Table 1

Detection of antibodies to parvovirus B19 in patients suffering from arthropathies, Belém, Pará, 1994-2000.

\begin{tabular}{|c|c|c|c|c|}
\hline \multirow[b]{2}{*}{$\begin{array}{c}\text { Sex/age } \\
\text { (years) }\end{array}$} & \multirow[b]{2}{*}{$\begin{array}{l}\text { Total } \\
\text { tested }\end{array}$} & \multicolumn{3}{|c|}{ Serological status $(\%)$} \\
\hline & & $\operatorname{IgM}+/ \operatorname{IgG}+$ & IgM-/IgG+ & IgM-/IgG- \\
\hline \multirow[b]{2}{*}{$\leq 10$} & 19 & $3(15.8)$ & $11(57.9)$ & $5(26.3)$ \\
\hline & 19 & $0(0)$ & $14(73.7)$ & $5(26.3)$ \\
\hline \multirow{3}{*}{$11-20$} & 28 & $1(3.6)$ & $21(75.0)$ & $6(21.4)$ \\
\hline & & & & \\
\hline & 27 & $2(7.4)$ & $19(70.4)$ & $6(22.2)$ \\
\hline \multirow[b]{2}{*}{$21-30$} & 26 & $4(15.4)$ & $20(76.9)$ & $2(7.7)$ \\
\hline & & & & \\
\hline M & 21 & $3(14.3)$ & $17(80.9)$ & $1(4.8)$ \\
\hline \multirow{3}{*}{$31-40$} & 20 & $3(15.0)$ & $17(85.0)$ & $0(0)$ \\
\hline & & & & \\
\hline & 19 & $0(0)$ & $17(89.5)$ & $2(10.5)$ \\
\hline \multirow{3}{*}{$>40$} & 21 & $2(9.5)$ & $17(81.0)$ & $2(9.5)$ \\
\hline & & & & \\
\hline & 20 & $1(5.0)$ & $16(80.0)$ & $3(15.0)$ \\
\hline $\mathrm{F}$ & 114 & $13(11.4)$ & $86(75.4)$ & $15(13.2)$ \\
\hline \multicolumn{5}{|l|}{ Subtotal } \\
\hline $\mathrm{M}$ & 106 & $6(5.7)$ & $83(78.3)$ & $17(16.0)$ \\
\hline Total & 220 & $19(8.6)$ & $169(76.3)$ & $32(14.6)$ \\
\hline
\end{tabular}



trop. S. Paulo, 44(1):17-22, 2002.

Table 2

Distribution of recent/active B19 infections associated with arthropathies, according to sex and age. Belém, Pará, 1994-2000.

\begin{tabular}{|c|c|c|c|c|c|}
\hline \multirow{2}{*}{$\begin{array}{l}\text { Sex/age } \\
\text { (years) }\end{array}$} & \multirow{2}{*}{$\begin{array}{l}\text { Total * } \\
\text { tested }\end{array}$} & \multicolumn{2}{|c|}{$\mathrm{IgM}+/ \operatorname{IgG}+(\%)$} & \multicolumn{2}{|c|}{ IgM-/IgG+** $(\%)$} \\
\hline & & DNA+ & DNA- & DNA+ & DNA- \\
\hline \multirow{2}{*}{$\leq 10^{\mathrm{F}}$} & 4 & $3(75.0)$ & $0(0)$ & $0(0)$ & $1(25.0)$ \\
\hline & & & & & \\
\hline $\mathrm{M}$ & 8 & $0(0)$ & $0(0)$ & $4(50.0)$ & $4(50.0)$ \\
\hline $\mathrm{F}$ & 13 & $2(15.4)$ & $0(0)$ & $9(69.2)^{\mathrm{a}}$ & $2(15.4)$ \\
\hline \multicolumn{6}{|l|}{$11-20$} \\
\hline $\mathrm{M}$ & 15 & $0(0)$ & $1(6.7)$ & $3(20.0)^{b}$ & $11(73.3)$ \\
\hline $\mathrm{F}$ & 22 & $4(18.2)$ & $0(0)$ & $6(27.3)$ & $12(54.5)$ \\
\hline \multicolumn{6}{|l|}{$21-30$} \\
\hline $\mathrm{M}$ & 19 & $2(10.5)$ & $1(5.3)$ & $6(31.6)$ & $10(52.6)$ \\
\hline $\mathrm{F}$ & 19 & $3(15.8)$ & $0(0)$ & $8(42.1)$ & $8(42.1)$ \\
\hline \multicolumn{6}{|l|}{$31-40$} \\
\hline $\mathrm{M}$ & 12 & $0(0)$ & $0(0)$ & $5(41.7)$ & $7(58.3)$ \\
\hline $\mathrm{F}$ & 9 & $2(22.2)$ & $0(0)$ & $3(33.3)$ & $4(44.5)$ \\
\hline \multicolumn{6}{|l|}{$>40$} \\
\hline $\mathrm{M}$ & 11 & $1(9.1)$ & $0(0)$ & $2(18.2)$ & $8(72.7)$ \\
\hline $\mathrm{F}$ & 67 & $14(20.9)$ & $0(0)$ & $26(38.8)^{\mathrm{c}}$ & $27(40.3)$ \\
\hline \multicolumn{6}{|l|}{ Subtotal } \\
\hline $\mathrm{M}$ & 65 & $3(4.6)$ & $2(3.1)$ & $20(30.8)^{d}$ & $40(61.5)$ \\
\hline Total & 132 & $17(12.9)$ & $2(1.5)$ & $46(34.8)$ & $67(50.8)$ \\
\hline
\end{tabular}

* A total of 88 serum samples not screened by PCR/ nested PCR .

** O.D of specimens, $>5$ times that O.D mean of cut off.

${ }^{\text {a vs }}{ }^{b}$ Significant difference between the results $(P=0.0006)$.

${ }^{c}$ vs d Significant difference between the results $(P=0.005)$. joints such as those of knee, ankle, pulse and shoulder were affected. As for the duration, symptoms lasted 1 to 5 days in $54.0 \%$ of the individuals, whereas in $46.0 \%$ of them the disease lasted 6-10 days, if considered the subgroup $(n=63)$ of patients with recent/active infection for the parvovirus B19. In our study, joint involvement occurred symmetrically (data not shown in Fig. 2).

Negative results were yielded when testing sera for antibodies to a variety of other pathogens that might be related to arthropathies in our region, including dengue virus.

\section{DISCUSSION}

The analysis of the serologic "status" in the group $(n=220)$ of subjects with arthropathies made it possible the selection of a subgroup ( $\mathrm{n}=132$ ) of patients who had presented high IgM+/IgG+ and IgM- / IgG+ antibody levels for B19. Overall, 132 of these serum samples were examined by PCR/nested PCR techniques, according to previous

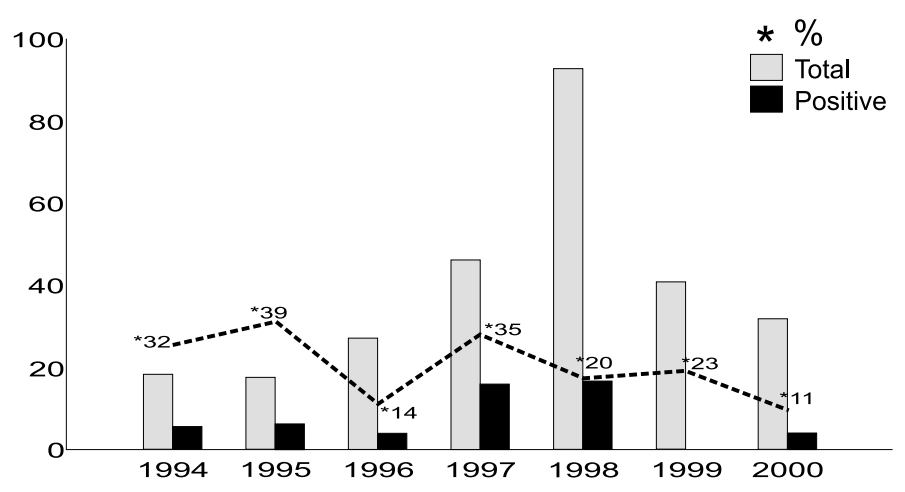

Fig. 1 - Temporal distribution of seropositivity to parvovirus B19 in patients suffering from arthropathies. Belém, Pará, 1994-2000.

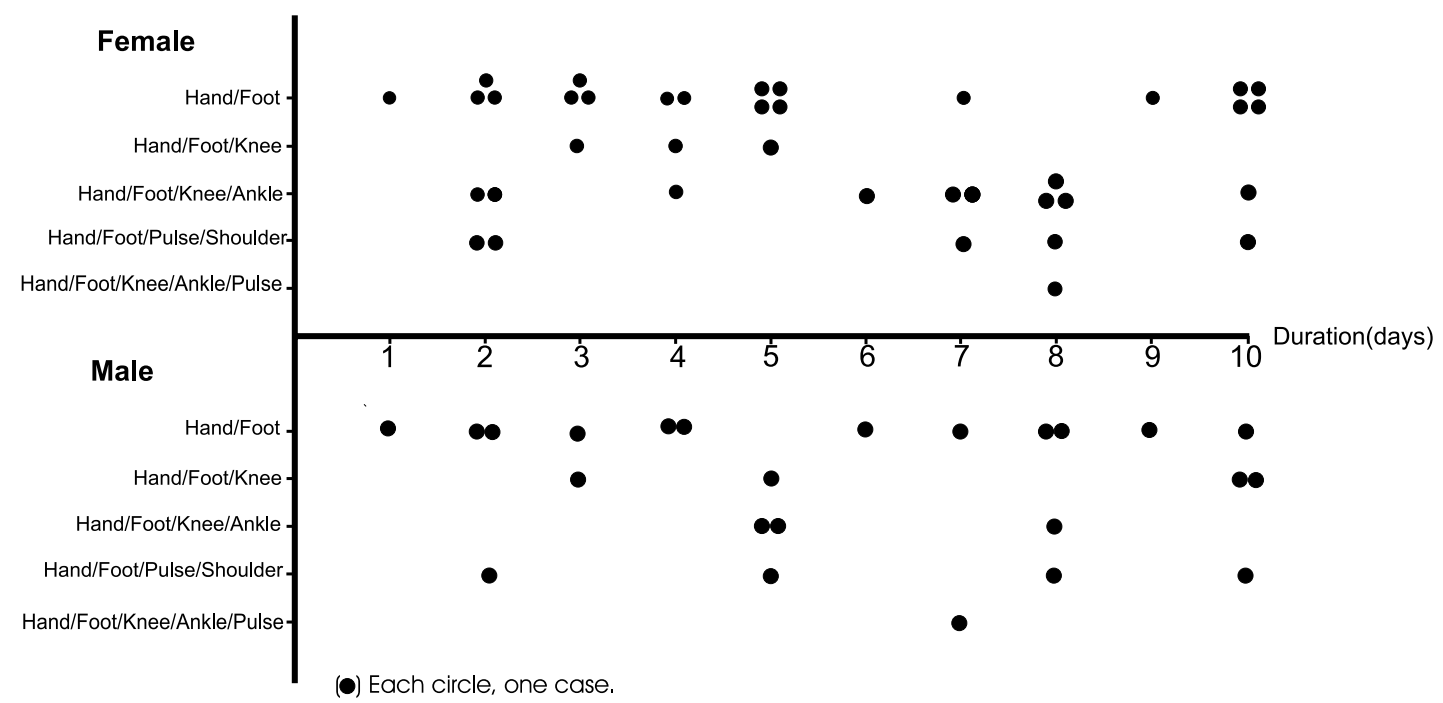

Fig. 2 - Anatomic localization and duration of the arthropathies associated with recent/active B19 infections, according to sex in 63 patients. Belém, Pará, 1994-2000. 
studies $^{10,32}$. These techniques present greater sensitivity than the ELISA, mainly in situations that require the diagnosis of recent/active B19 infection leading to joint manifestations ${ }^{9,26}$. This fact was confirmed by the results of this investigation, when comparing the number of recent/ active infections detected by ELISA and those detected by nested PCR: significant difference, as indicated by $\mathrm{P}=0.0001$. The absence of $\operatorname{IgM}$ antibodies for B19 in sera doesn't rule out the possibility of recent/active infection, since these sera may have B19 DNA if it contains high levels of IgM-/IgG+ antibodies. This condition, observed in our study, has already been demonstrated by CASSINOTTI et al. ${ }^{9}$. The sera not examined $(n=88)$ by PCR/nested PCR were those showing either no B19 specific IgG or low levels of B19 specific IgG antibodies detected by ELISA. In this study, the arthropathies prevailed among female patients (c vs $d, P=0.005$, Table 2 ), mainly among young women (a vs $\mathrm{b}, \mathrm{P}=0.0006$ ). A smaller proportion of male adults were affected, and cases of polyarthritis and polyarthralgy also involved children < 10 years. The frequency of joint manifestations associated with parvovirus B19 infection in our investigation was similar to that recorded for adults of both sexes in temperate countries ${ }^{24}$, with rates of positivity ranging from 30.0 to $59.0 \%$. However, for the children aged $<10$ years our rates were higher than they were for countries with temperate climate ${ }^{7}$. The explanation for this might be related to the rates of B19 primo-infections, recorded by FREITAS et al. ${ }^{22}$, among children with ages $<5$ years in Belém, Brazil, in general higher than those for temperate countries 5 .

The temporal distribution of B19 infection throughout our study period support the cyclic pattern proposed for the occurrence B19 infections, as recorded by FREITAS et al. ${ }^{21}$ in Belém, Pará, with peaks of viral activity at 3-5 year intervals. Of note, the high number of arthropathies recorded in 1998 were not associated with the B19 and other bacterial and/or parasitic agents investigated. This fact raises the possibility that pathogens not investigated in our study be associated with the disease, as demonstrated in others regions s $^{37,41,48,49}$. Because of situations like this, ${ }^{36,38,40}$ it has been stressed the importance of making differential diagnosis with arthropathies due to other pathogens, so that proper therapeutic measure can be taken. In our study, interfalangial joints of hands and feet were mostly affected. Less often, other joints such as those of knee, ankle, pulse and shoulder were affected. The arthropathies associated with the recent/active B19 infection presented short duration (maximum of 10 days), symmetrical distribution and disappeared without sequelae. These clinical features have been recorded in previous studies ${ }^{36,38}$. In our study, the absence of chronic arthropathies associated with parvovirus B19, as previously described ${ }^{34,36}$, could be explained by the fact that a low number of patients $(n=13)$ with chronic joint symptoms (lasting months or years) were enrolled in the present study. Therefore, arthropathies due to collagen or connective tissue diseases seemed not having prevailed among our study patients and there was no evidence that such cases were recent/active B19 infection.

In our study, arthralgy was more frequent than arthritis. The interfalangial joints (hands and feet) were more related arthralgy, mainly among women. These results were also reported in other studies ${ }^{36,38}$. Viruses other than B19, bacteria or parasitic agents capable to produce acute arthropathies in our region were ruled out as possible aetiological agents..$^{36,38}$

In our investigation, the frequent joint manifestations associated with parvovirus B19, mainly among women, indicate the need for laboratorial diagnosis of this viral agent, therefore avoiding unproper treatment.
The arthritis/arthralgy in pregnant women may constitute an important indicator of B19 infection, known to be potentially hazardous for the concept $\mathrm{t}^{3,27,28}$.

\section{RESUMO}

\section{Associação entre parvovírus B19 e artropatias em Belém, Pará, norte do Brasil}

Um total de 220 indivíduos portadores de artropatias foi selecionado em Belém, Pará, entre janeiro de 1994 e dezembro de 2000 e, posteriormente, examinado com o propósito de se detectarem anticorpos $\operatorname{IgM}$ e IgG para o parvovírus B19, utilizando-se a técnica imunoenzimática (ELISA). Um subgrupo $(\mathrm{n}=132)$ de indivíduos com amostras de soro apresentando altos níveis de anticorpos (IgM+/IgG+ e IgM-/IgG+) foi usado para detecção de DNA do B19 através da reação em cadeia da polimerase (PCR) e do "nested" PCR. Infecção recente/ativa (detecção de IgM e/ou IgG mais a presença de DNA viral) foi diagnosticada em $47,7 \%$ dos 132 indivíduos apresentando comprometimento das articulações. O sexo feminino foi mais afetado $(59,7 \%)$ que o masculino $(35,4 \%)$, com diferença estatisticamente significativa $(\mathrm{P}=0,0006)$. Os grupos etários mais atingidos foram os de 11-20 anos (84,6\%), no sexo feminino, e 21-30 anos (42,1\%), no masculino. A análise da distribuição temporal mostrou um padrão cíclico, com períodos de maior e menor atividade viral que variam de 3 a 5 anos. Diferença estatisticamente significativa $(\mathrm{P}=0,01)$ foi observada quando comparadas as freqüências de positividade mais alta $(39,0 \%)$ e mais baixa $(11,0 \%)$ para os anos de 1995 e 2000, respectivamente. As articulações mais atingidas foram, em ordem de frequiência, as interfalangianas de mãos e pés, com $50,0 \%$ e $48,0 \%$ para o sexo feminino e masculino, respectivamente. Em menor proporção outras articulações tais como as do joelho, tornozelo, pulso e ombro foram afetadas. Quanto à duração das manifestações articulares, $54,0 \%$ evoluíram por 1-5 dias, e 46,0\% ao longo de 6-10 dias, considerando o subgrupo $(\mathrm{n}=63)$ de indivíduos com infecção recente/ativa para o B19 em ambos os sexos. Em nosso estudo, o comprometimento das articulações apresentou caráter simétrico. Os resultados encontrados demonstraram o freqüente acometimento articular associado às infecções recentes/ativas por parvovírus B19, ressaltando a necessidade do diagnóstico laboratorial dessa virose, principalmente entre gestantes.

\section{ACKNOWLEDGMENTS}

We thank Dr. Elisabete Santos and Marinete Póvoa for carrying out the serological tests for rubella, measles, cytomegalovirus infections and Toxoplasma gondii. We are grateful to Dr. Pedro Vasconcelos for performing the serological tests for Mayaro, Oropouche and dengue viruses. Thanks are also due Mrs. Edna Filizzola for technical assistence.

\section{REFERENCES}

1. ADEBONOJO, F.O. - Monoarticular arthritis: an unusual manifestation of infectious mononucleosis. Clin. Pediat., 11: 549-550, 1972.

2. AGER, E.A.; CHIN, T.D.Y. \& POLAND, J.D. - Epidemic erythema infectiosum. New Engl. J. Med., 275: 1326-1331, 1996.

3. ANAND, A.; GRAY, E.S.; BROWN, T.; CLEWLEY, J.P. \& COHEN, B.J. - Human parvovirus infection in pregnancy and hydrops fetalis. New Engl. J. Med., 316: 183-186, 1987. 
4. ANDERSON, L.J. - Human parvoviruses. J. infect. Dis., 161: 603-608, 1990.

5. ANDERSON, L.J. - Role of parvovirus B19 in human disease. Pediat. infect. Dis. J., 6 : 711-718, 1987.

6. ANDERSON, L.J.; TSOU, R.A.; CHORBA, T.L. et al. - Detection of antibodies and antigens of human parvovirus B19 by enzyme-linked immunosorbent assay. J. clin. Microbiol., 24: 522-526, 1986.

7. ANDERSON, M.J.; LEWIS, E.; KIDD, I.M.; HALL, S.M. \& COHEN, B.J. - An outbreak of erythema infectiosum associated with human parvovirus infection. J. Hyg. (Lond.), 93: $85-93,1984$

8. CAMARGO, M.E.; LESER, P.G. \& LESER, W.S.P. - Diagnostic information from serological tests in human toxoplasmosis. I. A comparative study of hemagglutination, complement fixation IgG and IgM - immunofluorescence tests in 3,752 serum samples. Rev. Inst. Med. trop. S. Paulo, 18: 215-226, 1976.

9. CASSINOTTI, P.; BAS, S.; SIEGL, G. \& VISCHER, T.L. - Association between human parvovirus B19 infection and arthritis. Ann. rheum. Dis., 54: 498-500, 1995.

10. CASSINOTTI, P.; WEITZ, M. \& SIEGL, G. - Human parvovirus B19 infections: routine diagnosis by a new nested polymerase chain reaction assay. J. med. Virol., 40: 228234, 1993.

11. CAUL, E.O.; USHER, M.J. \& BURTON, P.A. - Intrauterine infection with human parvovirus B19: a light and electron microscopy study. J. med. Virol., 24: 55-66, 1988.

12. CHERNESKY, M.A.; WYMAN, L.; MAHONY, J.B. et al. - Clinical evaluation of the sensitivity and specificity of a commercially available enzyme immunoassay for detection of rubella virus - specific immunoglobulin M. J. clin. Microbiol., 20: 400 404, 1984.

13. CHORBA, T.; COCCIA, P.; HOLMAN, R.C. et al. - The role of parvovirus B19 in aplastic crisis and erythema infectiosum (fifth disease). J. infect. Dis., 154: 383-393, 1986.

14. COHEN, B.J.; MORTIMER, P.P. \& PEREIRA, M.S. - Diagnostic assays with monoclonal antibodies for the human serum parvovirus- like virus (SPLV). J. Hyg. (Lond.), 91:113-130, 1983.

15. COSSART, Y.E..; FIELD, A.M.; CANT, B. \& WIDDOWS, D. - Parvovirus-like particles in human sera. Lancet, 1(7598): 72-73, 1975.

16. CUBEL, R.C.N.; VALADÃO, M.C.; PEREIRA, W.V.; MAGALHÃES, M.C. \& NASCIMENTO, J.P. - Aplastic crisis due to human parvovirus B19 infection in hereditary hemolytic anaemia. Rev. Inst. Med. trop. S. Paulo, 34: 479-482, 1992.

17. DEBYSER, Z.; REYNDERS, M.; GOUBAU, P. \& DESMYTE, J. - Comparative evaluation of three Elisa techniques and an indirect immunofluorescence assay for the serological diagnosis of Epstein - Barr virus infection. Clin. diagn. Virol., 8: 71$81,1997$.

18. DURIGON, E.L.; ERDMAN, D.D.; GARY, W.G. et al. - Multiple primer pairs for polymerase chain reaction (PCR) amplification of human parvovirus B19 DNA. J. virol. Meth., 44: 155-165,1993.

19. FERREIRA, E.C. - Toxoplasmose. In: NEVES, J., ed. Diagnóstico e tratamento das doenças infectuosas e parasitárias. Rio de Janeiro, Guanabara Koogan, 1978. p. 671-686.

20. FOTO, F.; SAAG, K.G.; SCHAROSCH, L.L.; HOWARD, E.J. \& NAIDES, S.J. Parvovirus B19 - specific DNA in bone marrow from B19 arthropathy patients: evidence for B19 virus persistence. J. infect. Dis., 167: 744-748, 1993.

21. FREITAS, R.B.; MIRANDA, M.F.R.; SHIRLEY, J. et al. - Parvovirus B19 antibodies in sera of patients with unexplained exanthemata from Belém, Pará, Brazil. Mem. Inst. Oswaldo Cruz, 88: 497-499, 1993.
22. FREITAS, R.B.; WONG, D.; BOSWELL, F. et al. - Prevalence of human parvovirus (B19) and rubellavirus infections in urban and remote rural areas in Northern Brazil. J. med. Virol., 32: 203-208,1990.

23. FRIEDMAN, H.M.; PINCUS, T.; GIBILISCO, P. et al. - Acute monoarticular arthritis caused by herpes simplex virus and cytomegalovirus. Amer. J. Med., 69: 241-247, 1980 .

24. HAILE, C.A. - Parvovirus and epidemic arthritis. Maryland med. J., 39: 939-944, 1990

25. HELFAND, R.F.; KEBEDE, S.; ALEXANDER Jr., J.P. et al. - Comparative detection of measles - specific IgM in oral fluid and serum from children by an antibody - capture IgM EIA. J. infect. Dis., 173: 1470-1474, 1996.

26. KERR, J.R.; CARTRON, J.P.; CURRAN, M.D. et al. - A study of the role of parvovirus B19 in rheumatoid arthritis . Brit. J. Rheum., 34: 809-813, 1995.

27. KERR, J.R.; O'NEILL, H.J.; COYLE, P.V. \& THOMPSON, W. - An outbreak of parvovirus B19 infection: a study of clinical manifestations and the incidence of fetal loss. Irish J. med. Sci., 163: 65-67, 1994

28. KINNEY, J.S.; ANDERSON, L.J.; FARRAR, J. et al. - Risk of adverse outcomes of pregnancy after human parvovirus B19 infection. J. infect. Dis., 157: 663-667, 1988.

29. LAZZAROTTO, T.; DALLA CASE, B.; CAMPISI, B. \& LANDINI, M.P. - Enzymelinked immunosorbent assay for the detection of cytomegalovirus-IgM: comparison between eight commercial kits, immunofluorescence and immunoblotting. J. clin. Lab. Anal., 6: 216-218, 1992.

30. LIMA, A.O.; SOARES, J.B.; GRECO, J.B.; GALIZZI, J. \& CANÇADO, J.R., ed. Provas sorológicas. In: LIMA, A.O. Métodos de laboratório aplicados à clínica. 4 ed. Rio de Janeiro, Guanabara Koogan, 1969. p. 298-299.

31. MOTA, C.C.C.; OLIVEIRA, L. \& MEIRA, Z.M.A. - Febre reumática. In: TONELLI, E \& FREIRE, L.M.S. Doenças infecciosas na infância e adolescência. 2 ed. Rio de Janeiro, Guanabara Koogan, 2000. p. 353-370.

32. MUSIANI, M.; AZZI, A.; ZERBINI, M. et al. - Nested polymerase chain reaction assay for the detection of B19 parvovirus DNA in human immunodeficiency virus patients. J. med. Virol., 40: 157-160, 1993.

33. NAIDES, S.J. - Parvovirus B19 infection. Rheum. Dis. Clin. N. Amer., 19: 457-475,1993.

34. NAIDES, S.J.; FOTO, F.; MARSH, J.L. et al. - Synovial tissue analysis in patients with chronic parvovirus B19 arthropathy. Clin. Res., 39: 733A, 1991.

35. NIKKARI, S.; ROIVAINEN, A.; HANNONEN, P. et al. - Persistence of parvovirus B19 in synovial fluid and bone marrow. Ann. Rheum. Dis., 54: 597-600, 1995.

36. NOCTON, J.J.; MILLER, L.C.; TUCKER, L.B. \& SCHALLER, J.G. - Human parvovirus B19 - associated arthritis in children. J. Pediat., 122: 186-190, 1993

37. OLIVEIRA, S.A.; BRANDÃO, A.B.; FERNANDES, D.G. et al. - Human parvovirus B19 infection: clinical and epidemiological study of 24 cases. Rev. Inst. Med. trop. S. Paulo, 38: 323-327, 1996

38. OLIVEIRA, S.A.; CAMACHO, L.A.B.; BETTINI, L.R. et al. - Manifestações articulares nas viroses exantemáticas. Rev. Soc. bras. Med. trop., 32: 125-130, 1999.

39. PRINGLE, C.R. - Virus taxonomy update. Taxonomic decisions ratified at the plenary meeting of the ICTV at the $9^{\text {th }}$ International Congress of Virology held in Glasgow on $10^{\text {th }}$ of August 1993. Arch. Virol., 133: 491-495, 1993.

40. REID, D.M.; REID, T.M.S.; BROWN, T.; RENNIE, J.A.N \& EASTMOND, C.J. Human parvovirus- associated arthritis: a clinical and laboratorial description. Lancet, 1: $422-425,1985$

41. RUIZ, F.J.M.; TERÉS, M.O.; AZNAR, C.P. \& RUIZ, I.M. - Poliartritis aguda asociada a infección por parvovirus B19. An. Med. interna (Madrid), 17:153-154, 2000. 
42. SAARINEN, U.M.; CHORBA, T.L.; TATTERSALL, P. et. al. - Human parvovirus B19induced epidemic acute red cell aplasia in patients with hereditary hemolytic anemia. Blood, 67: 1411-1417, 1986

43. SALIMANS, M.M.M.; VAN BUSSEL, M.J.A.W.M.; BROWN, C.S. \& SPAAN, W.J. Recombinant parvovirus B19 capsids as new substrate for detection of B19-specific IgG and IgM antibodies by an enzyme-linked immunosorbent assay. J. virol. Meth., 32: $247-258,1992$

44. SCROGGIE, D.A.; CARPENTER, M.T.; COOPER, R.I. \& HIGGS, J.B. - Parvovirus arthropathy outbreak in southwestern United States. J. Rheum., 27: 2444-2448, 2000.

45. SEYAMA, K.; KOBAYASHI, R.; HASLE, H. et al. - Parvovirus B19 - induced anemia as the presenting manifestation of $\mathrm{X}$-linked hyper-IgM syndrome. J. infect. Dis., 178: $318-324,1998$

46. SHOPE, R.E. - The use of a microhemagglutination - inhibition test to follow antibody response after arthropod - borne virus infection in a community of forest animals. An. Microbiol. (Rio de J.), 11(parte A): 167-171, 1963.

47. SMITH, M.A. \& RYAN, M.E. - Parvovirus infections: from benign to life threatning. Postgrad Med., 84: 127-134, 1988.
48. STAHL, H.D. HUBNER, B. SEIDL, B. et al. - Detection of multiple viral DNA species in synovial tissue and fluid of patients with early arthritis. Ann. rheum. Dis., 59: $342-346,2000$

49. STAHL, H.D.; SEIDL, B.; HUBNER, B. et al. - High incidence of parvovirus B19 DNA in synovial tissue of patients with undifferentiated mono - and oligoarthritis. Clin. Rheumat., 19: 281-286, 2000 .

50. TÖRÖK, T.J. - Parvovirus B19 and human disease. Advanc. intern. Med., 37: 431-455 1992.

51. TRAVASSOS da ROSA, A.P.A.; PINHEIRO, F.P.; TRAVASSOS da ROSA, E.S. et al. Arboviroses. In: TONELLI, E. \& FREIRE, L.M.S. Doenças infecciosas na infância e adolescência. 2. ed. Rio de Janeiro, Guanabara Koogan, 2000. p. 986-1015.

52. UENO, Y.; UMADOME, H.; SHIMODERA, M. et al. - Human parvovirus B19 and arthritis. Lancet, 341: 1280, 1993.

53. WOOLF, A.D.; CAMPION, G.V.; CHISHICK, A. et al. - Clinical manifestations of human parvovirus B19 in adults. Arch. intern. Med., 149: 1153- 1156, 1989.

Received: 8 October 2001

Accepted: 28 December 2001 